\title{
An Interview with Professor Jonathan King. Part II: on the Influence of Private Funding on Public Policy
}

\author{
Manraj S. Gill ${ }^{1, *}$, Jennifer A. Cascino ${ }^{1}$, and Dylan M. McCormick ${ }^{1}$
}

In his many years of advocacy efforts from within academia, Professor King has centered the issue of nuclear weapons disarmament. His numerous initiatives within this realm emphasize that disarmament is fundamentally a question of funding, making clear that a society that prioritizes the funding of warfare does so at the cost of failing to fortify public health and healthcare. Dr. King currently chairs the Nuclear Disarmament Working Group of Mass Peace Action (MPA), a nonprofit that works to generate political momentum toward "a more just and peaceful U.S. foreign policy" [1]. At MPA, he has also helped to organize the Healthcare not Warfare campaign, which calls for the prioritization of tax dollars toward healthcare, housing, public transport, food security, and education through major cuts to the annual federal military budget.

His career-long critique of the military-industrial complex stems from his days participating in Science for the People, an organization that emerged from the antiwar culture of the late 1960s to push the scientific establishment to approach science as a social endeavor by using scientific discoveries for the advancement of social causes rather than profit-making and warfare. His advocacy work critically examines the links between funding, public policy, and the types of societies that we build.

In part II, we explore these issues with Professor King to gain his perspective on the relationship that funding (of higher education, lobbying, research) has with the social and scientific institutions that we configure.

Science Policy Review: We're curious about how education and scientific research should be funded. Historically, the model has shifted between regimes with a greater dependence on corporate/private sponsors or the taxpayer. What do you envision as solutions to addressing disparities between resource-rich and resource-poor institutions?

Jonathan King: In this period of 1960 s to 2000 , the US was the world leader in science and technology across the board. Why was the US the world leader? One part of it was public funding, but the second was a scientific workforce that came together from all across the country. This pattern started from linking the land-grant universities and led to an enormous

\footnotetext{
${ }^{1}$ Department of Biology, Massachusetts Institute of Technology, Cambridge, MA *Email: manraj@mit.edu

The authors declare no conflict of interest. The opinions presented here represent the opinion of the speaker, not MIT Science Policy Review.

(C) 2021 The Author(s)
}

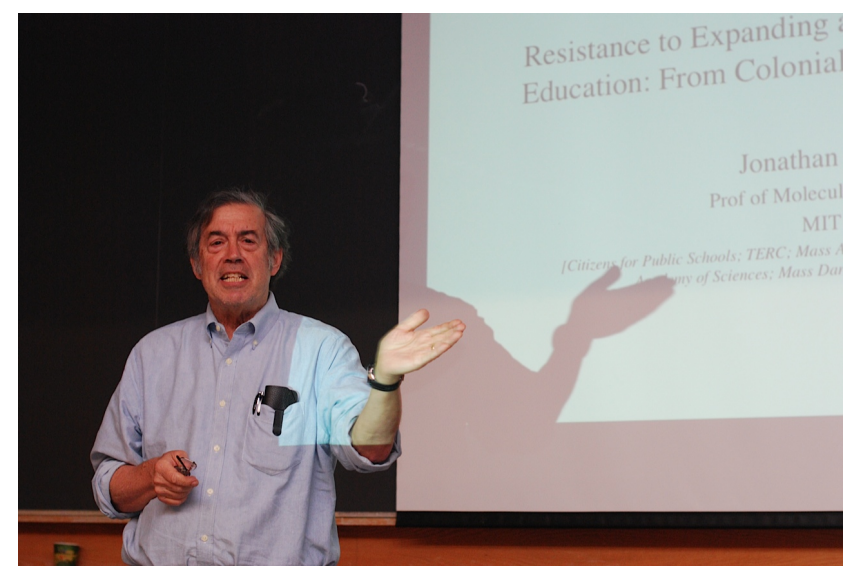

Figure 1: Professor Jonathan King speaking at an MIT Education Group seminar on the 'Resistance to Expanding and Enhancing STEM Education' [2].

geographical diversity in the scientific workforce.

However, after Reagan, you see a systematic reduction in public funding of public universities. Absolutely systematic. So that state universities like UMass Amherst that used to be 80 percent supported by the state government are now 15 percent supported by the state government, and they have to go outside and find private or federal funds. That should be reversed in order to ensure that the public colleges and universities aren't starved compared to the Harvards and Princetons.

And then, we need much increased federal support for higher education. You all know that biomedical research money supports higher education in general. Graduate students in the biology department are Teaching Assistants (TAs) of undergraduates, which is about education and not biomedical research, because of funds from the National Institutes of Health (NIH).

However, within the lobbying apparatus of the NIH budget, which I participate in as a member of the Biophysical Society, people are completely silent about this role of $\mathrm{NIH}$ funding in supporting higher education because the Republicans oppose federal support for higher education. So, there's no explicit line item in the federal budget that mentions NIH support for higher education - that ought to be explicitly in there. Expanding or doubling the NIH budget, most of the money from which would go to colleges and universities, would be a significant 
step forward.

Lastly, within state legislatures, there's been a constant reduction of the state income stream by giving businesses, millionaires, and hedge fund managers tax breaks. And now we have, for the first time, a robust effort in the Massachusetts state legislature to raise the state revenue. We have to tax millionaires, real estate transactions, and stock market transactions. That would increase the budget available for the UMass campuses and the UMass public system.

"The best historical example

contributing to the diminishing

public trust in science is the invisible

suppression of areas of research."

SPR: On this idea of local access to higher education and practicing research seeming limited in most parts of the country, and the emergence of a handful of universities receiving a majority of federal funds... What are your thoughts on limiting how much federal taxpayer money can go to a single institution?

JK: The NIH has had a small college program for a long time, so faculty at small colleges do get grants. I've had a number of students who've spent their lives in small institutions and they've had research grants all their lives. The problem isn't research grants to the faculty, the problem is that they have a student body under much higher economic pressure. One of my students, Chris Bazinet, was on the faculty at St. John's in Queens, whose student population is largely an immigrant population and often with very low income. They had graduate students, but most of their graduate students were parents or were financially supporting their families. So, that is where proposals like free public college are likely to be more beneficial than specific budget allocations at the National Science Foundation (NSF) or $\mathrm{NIH}$.

SPR: An eventual consequence of the clear diminishing trust of the broader public in the enterprise of science and its technological applications may well be a reduction in public funding of science. What do you envision as an actionable path forward towards remediating the consequences of past inaction, restoring the public's trust, and legitimizing the pursuit of science in our society?

JK: The best historical example contributing to the diminishing public trust in science is the invisible suppression of areas of research... The US medical community and pharmaceutical community is focused on the patient: Why did you get sick? Perhaps you didn't behave right? Perhaps you're under stress? The external causes of disease - lead poisoning, mercury poisoning, vinyl chloride, PCBs - are actively suppressed.

This has come to a head a number of times, but the most important example is the early death of coal miners from black lung disease. Organizations like the NIH were just completely ignoring black lung disease. The physicians either didn't know about these diseases, or if they knew, they learned to keep their mouths shut about it. The pushback from the coal workers' union brought into existence the National Institute for Occupational Safety and Health. Unfortunately, that was not put in Bethesda with all the other NIH offices, it was put out in Cincinnati and has had a very limited budget and very mild and ineffective leadership. If these agencies were better positioned financially and authoritatively, then you could have a series of agencies that could neutralize some of the effect of the private sector (the industrial organizations, pharmaceutical manufacturers, and the US Chamber of Commerce), all of which act to suppress research on the causes of disease within the scientific community.

This invisible suppression of areas of research is also prevalent in the field of diabetes. If you look at the $\mathrm{NIH}$ portfolio, there are no studies that ask the question, "Is there an environmental link?"

And the same is true in cardiology. "Why do you have a heart problem? You're under stress, you're not eating right, you're not exercising." Then you discover that, if you read the court documents - not scientific documents that among people who took this compound called Vioxx, roughly 2000 had heart valve damage. You might think, "Maybe heart valve damage is due to exposure to some compound in the environment?" And maybe you have a little $\mathrm{NIH}$ epidemiological study, but none exist!

And why not? Because the pharmaceutical industry is watching that like a hawk. The only way that the Eli Lilly and Company makes billions of dollars a year on selling insulin to diabetics is the fact that there are 10 million diabetics a year. They have no interest in reducing the incidence of diabetes. That's the basis of their industry: people getting sick year after year after year. They've been in this business for 50 years, and they know how to nip in the bud any discussion of an environmental cause of disease which would make it preventable.

SPR: Could you comment on any instances of such invisible suppression of areas of research at MIT?

JK: That kind of discussion also never happens at MIT! When Koch (David H. Koch), the guy leading the effort nationally to suppress research on environmental carcinogens, put his name on the MIT cancer institute, some of us said, "You know, maybe there's a little contradiction in having Koch be the leading financier of the cancer institute?" But nobody in the cancer institute would say a word. So you can have a situation where the head of the cancer institute is giving a research seminar on his work, which is on lung cancer, and Koch is sitting right there in the first row, and cigarette smoke is not mentioned in the whole seminar on lung cancer. It's all about once the cells have made the transition to being tumor cells, what can we do to interfere? What really does cause disease needs to be tackled.

And you are kind of tackling capitalism as an economic system when you do that because the suppression of research 
is grounded in these private corporate research investments.

SPR: It seems a lot of what we have just talked about does come up against our framework as a capitalist society that values privatization and individualized efforts rather than collective investment in social goods. And often, discussions to try to change funding structures come up against people calling those who are trying to have the conversation "socialist" or "unamerican." What are your thoughts on this equation?

JK: That's a very legitimate question. Luckily you brought it up because I would've stayed away from it. In my Science for the People days, some of my colleagues and I investigated what happened to the scientific community after the revolution in Cuba. There, there were some people who said that, for example, in ecology and evolution, the emphasis on competition rather than cooperation comes from the capitalist funding of the sciences. And that in a socialist society you would be able to have people investigate the role of cooperation and raise it up. There's a famous book called Mutual Aid that documents among how many species what actually goes on. The notion that bees and the flowers that they pollinate are in competition - totally absurd! These are situations that absolutely depend on cooperation. All these animals that move as flocks work together. But in the United States, in the West, that isn't there.

SPR: Another prevalent theme here seems to be that financial lobbying dictates what ends up being done in the educational and science policy realm. This has also been true in the larger political landscape, as emphasized most notably by the discussions around campaign finance reform and the 2010 US Supreme Court decision in Citizens United vs Federal Election Commission. How have your thoughts on this topic developed and what have you learned about this type of influence through your work on nuclear disarmament?

JK: Let's initially talk a little bit about nuclear disarmament, which is not a very popular social issue or academic issue nowadays, but it's true that there are still thousands upon thousands of such weapons on trigger alert and that countries like the US have this policy of not needing congressional approval for their launch. A terribly scary and nightmarish situation. And the situation is totally absurd and probably the biggest boondoggle in human history. If these weapons are ever used, everybody dies. The notion that they increase national security is totally absurd.

One of the things that the industry does is that they finance people who fog the truth with misstatements. I recently went to a seminar about the India-Pakistan situation, two densely populated neighboring countries whereby an Indian nuclear attack on Pakistan would kill millions of Indians and a Pakistani nuclear attack on India would kill millions of Pakistanis. The notion that these weapons bring security to either country's population is totally absurd! But this guy who is from the international security program on an airforce fellowship argued about the reasonableness of and the basis of having two

\section{competing programs.}

So, what's really going on is that you have this massive nuclear weapons industry, which is enormously profitable and is completely a monopoly because you can't outsource these contracts to other countries. It is protected by congressional legislation: no matter how inefficiently they build the weapons, they are guaranteed a set profit margin on top. You can't even audit it because national security concerns provide a veil of secrecy so you're prevented from examining what actually goes on.

These people will fight to death to protect their monopoly and they are funded by our tax dollars so they're washed in cash; some fraction of which they recycle back into influencing congressional election campaigns and local newspapers.

A company like Raytheon, for example, the moment they hear of somebody thinking of running for office, or a sitting senator, or a sitting state representative who starts talking about whether Raytheon shouldn't be selling missiles to Saudi Arabia, they look for a right wing opposition candidate to run against them. People on the inside learn this, they don't talk about it, but they learn that "Don't take on Raytheon" because Raytheon will organize a fight back. So, once you know that, you can't expect normal people to take on nuclear weapons or the military-industrial complex, it's a very powerful and insidious enemy.

But it's also a very important issue. So, to someone like me who doesn't need to publish-or-perish - my career is behind me - and has a lot of experience in organizational politics, it seemed to me that this struggle that no one wants to participate in is absolutely essential and is an issue that the whole world's population would be affected by.

"One of the things that the industry does is that they finance people who fog the truth with misstatements... The massive nuclear weapons industry will fight to death to protect their monopoly by influencing congressional election campaigns and local newspapers."

On the other hand, our efforts have been without effect. For years, and years, and years, we haven't had any effect. In our group, we're watching the Biden-Harris administration very closely and hoping they will take some steps.

However, I don't believe that the reigning in of the military-industrial complex is going to happen by any direct focus on them. My guess is that the pressure to get more investment into pandemic-control, public health, and healthcare will put downward pressure on that budget. Senator Markey is introducing a bill, the first time anything like this has even been introduced - just being introduced, who knows whether it will even be debated — where he calls for defunding 
the new generation of intercontinental ballistic missiles and instead transferring the funding into the CDC for vaccine development.

So, normally where you're told there's no relationship between the weapons budget and the healthcare budget, that they're two separate pots, that's not true. There's just one congressional discretionary budget (see Figure 2). This is maybe the beginning of a broader group of Americans coming to understand that even if these weapons are never fired, the enormous cost of developing them is undermining the people's health and welfare. Am I confident that this will work? No! I just hope that we'll get control of that sector before they blow the world up.

One of the sad things is that we deal with the climate control group who are not interested in nuclear weapons disarmament. Now if these weapons go off, we won't have to worry about global warming! So you'd think they'd recognize that there are two existential risks here: global warming and nuclear war.

\section{"This is maybe the beginning of a \\ broader group of Americans coming \\ to understand that even if these \\ weapons are never fired, the \\ enormous cost of developing them is \\ undermining the people's health and \\ welfare."}

SPR: You briefly alluded to this and it pertains to one of the concepts we're interested in, namely advice on picking where to direct one's focus. Could you elaborate on when you chose to specifically act upon this issue of nuclear weapons disarmament? At what stage of your career did you decide this was an issue you could take on with some directed focus and energy?

JK: In my middle years, it was biological weapons that I worked on. And there we were much more successful because we got and still have a biological weapons treaty that is very strong. We got that before there was a big biotech industry, so there weren't big profits to be made. Now we have a situation through homeland security where they've really revived biological weapons programs in the name of national defense. And now there are lots and lots of contracts out there to study, for example, what happens if Ebola virus were to be modified.

I worked on that and general pentagon budget issues, but I then decided to focus on nuclear weapons when I read about an event, a very discreet event: a fire accident in Arkansas in one of the silos, and it almost led to nuclear detonation in Arkansas. It was described vaguely at first but then in detail in a book called Command and Control that was published about 5 years ago. Because it happened domestically, there were reports in the Sheriff's department, the fire department, and it was possible to reconstruct what had actually happened, and
2019 Discretionary Outlays: \$1.338 Billion

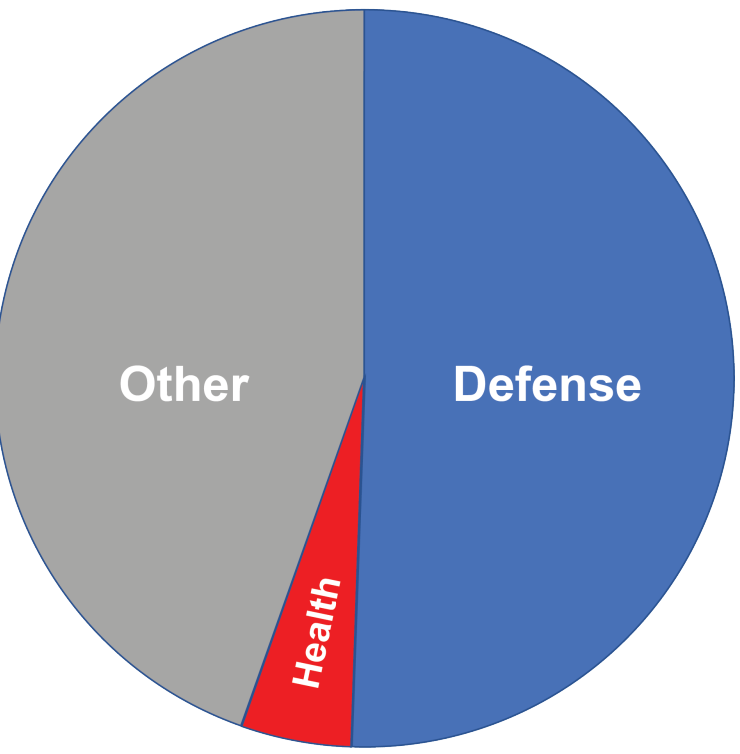

Figure 2: Defense spending accounts for roughly half of the total Congressional discretionary budget. Adapted from the Peter G. Peterson Foundation [3].

they couldn't claim that that effort was an effort of any Russian spies. And I read that and realized that there are all these other silos and I learned about all the other accidental cases and cases of bombs being dropped due to carelessness. I realized that this desperately needs attention and was perhaps the right issue to take on for someone who doesn't need stroking or social reward.

\section{References}

[1] Massachusetts Peace Action. About (2021). URL http:// masspeaceaction.org/about/.

[2] The Education Group at MIT. Seminar Archive: Professor Jonathan King (2012). URL http://educationgroup.mit. edu/HHMIEducationGroup / ?p=2175.

[3] Peter G. Peterson Foundation. Defense spending accounts for about half of total discretionary spending (2020). URL https://www.pgpf.org/sites/default/files/0070_ discretionary_spending_categories.pdf.

\section{Open Access}

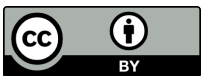

This MIT Science Policy Review article is licensed under a Creative Commons Attribution 4.0 International License, which permits use, sharing, adaptation, distribution and reproduction in any medium or format, as long as you give appropriate credit to the original author(s) and the source, provide a link to the Creative Commons license, and indicate if changes were made. The images or other third party material in this article are included in the article's Creative Commons license, unless indicated otherwise in a credit line to the material. If material is not included in the article's Creative Commons license and your intended use is not permitted by statutory regulation or exceeds the permitted use, you will need to obtain permission directly from the copyright holder. To view a copy of this license, visit http://creativecommons.org/licenses/ by $/ 4.0 /$. 